\title{
Managing Innovation Indicators: A Systematic Literature Reviews
}

\author{
Eddy Irsan Siregar \\ Faculty of Economics \& Business, Muhammadiyah Jakarta, University, Indonesia J1. Ahmad Dahlan Ciputat \\ Indonesia.15419
}

\begin{abstract}
Innovation Management is a process to manage innovation in a company so that it would be useful to create enterprises performance. There is a need of strong indicators as the support for Managing Innovation in terms of the availability of R \& D Department, Risk Taking, Openness \& Fortitude, and Failure Acceptances. In this paper, a systematic literature review of studies related to managing innovation is discussed. Literature review of customer involvement perspective from several journal will be conducted in this study. The objective of this study is to get a deeper knowledge of the definition of Managing Innovation. This study will be using a systematic literature review based on Kitchenham and Weerakkody study. Based on several criteria that are stated by author, the result is 18 papers which conclude that managing innovation will increase entreprises performance.
\end{abstract}

Keywords: managing innovation, Availability of R \& D Department, Risk Taking, Openness and Fortitude, Failure Acceptance

\section{INTRODUCTION}

Competitive method that has been used by many companies in Indonesia is to use comparative advantage, such as cheap labor and abundant natural resources, which is no longer appropriate for nowadays and future. The company face competitive environment that change very rapidly due to the influence of communication technology, information technology, and technology to produce goods and services more efficient, effective, and productive. In order to possess high competitiveness, the company needs to explore its ability to create value added by using the ability to innovate (Porter \& Heppelman 2014, in the Journal "How Smart Connecting People").

The ability to innovate is not enough to be left or handed over to the R \& D team and expert staff in the company, but it should also be facilitated, encouraged, and coordinated among various areas or departments led by a special team to handle it (J. Tidd \& Bessant, 2011, in the book "Managing Innovation").

The definition of Managing Innovation is as follows: Innovation Management is a process to manage innovation in a company so that it would be useful to create sustainable competitive advantage for such company. Innovation Management is necessary to acknowledge that fresh ideas should continue to flow at any time and as quickly as possible to anticipate the world development that is more rapid, diverse, and dynamic.

The indicators of Managing Innovation are as follows:

1. Availability of R \& D Department

2. Risk Taking

3. Openness and Fortitude

4. Failure Acceptance

Source: Schumpeter (1960), Porter \& Heppelman (2014), J.Tidd \& Bessant (2011), processed by author.

The question of this study is as follows: "Does the indicator affect managing innovation?"

Literature review of Managing Innovation from several journals will be conducted in this study. The objective of this study is to get a deeper understanding about the definition of managing innovation

\section{Methodology}

This study utilises the SLR approach that was proposed by Weerakkody et al. (2013) and Taha et al. (2013). This approach is divided into several sections, which are: defining research question that was explained on introduction, determining research sources, accomplishing the finding process by using keywords, extracting data, and analyzing the findings to answer research questions.

\subsection{Search Process}

After defining the research question, settling down the sources (digital libraries or databases) is very necessary to create the SLR.

The selected sources for SLR are as follows: Search process includes the selected sources and keywords. Selected sources are:

1. Science Direct (www.sciencedirect.com),

2. ACM Digital Library (www.dl.acm.org), 
3. IEEE Xplore (www.ieexplore.ieee.org), and

4. Google Scholar (www.scholar.google.com)

The keywords have been focused on "Managing Innovation", "model," and "indicator" with the synonym possibilities as shown in Table 1 .

Table 1. The Synonym of Managing Innovation and Indicators

\begin{tabular}{cc}
\hline Word & Synonim \\
\hline \multirow{2}{*}{ Managing Innovation } & Innovation Managing \\
\cline { 2 - 2 } & Innovation Management \\
\hline Indicator & Index \\
\hline \multirow{2}{*}{ Model } & Plan \\
\hline
\end{tabular}

Keywords are used to find papers that are related to the defined research question. The usage of keywords is enabled by adding Boolean operator such as: AND, OR, NOT.

All of the above-mentioned sources possess a keyword-based search engine. To find a keyword, the defined search strings are:

* (“index" OR “indicator”) AND (“plan" OR “design OR "model”) AND ("Managing Innovation” OR

"Innovation Management")

* ("index" OR “indicator") AND (“Managing Innovation" OR"Innovation Management”)

In order that the search results is more up to date, the paper of manuscript journal will be limited only as follows:

- $\quad$ Published year after 2010 and before 2017

- Duplicating papers

- Deep technical issue.

\section{RESULT}

Based on the introduction and methods that already stated, it is clear that the research question of this study will be answered, so the next stage is to set up the search process. To get prominent information, the author will be using digital libraries or database. This setting is necessary in the process of systematic literature review (SLR). The selected sources for this SLR are using Science Direct (www.sciencedirect.com), ACM Digital Library (dl.acm.org), IEEE Xplore (ieeexplore.ieee.org), and Google Scholar (scholar.google.com). The usage of keywords is applied to journals that are related with the research questions.

Right after the author search in that keyword, then the related papers are shown. The next step is to read the title and short explanation for each paper. Since too many results found, the author should make an inclusion and exclusion criteria. By utilize this method, the author could narrow down the search results that he wants to find. Thus, the author should set up the inclusion criteria by several scholarly journals and subjects that are related with the marketing and consumption behavior. To gain more new knowledge, the author uses the papers published from 2010 until 2016. Based on several criteria that are stated by author, the result is 18 papers stipulated in Table 2 and Table 3:

Table 2. Detail of Selected Paper

\begin{tabular}{cccc}
\hline Source & Studies Found & Candidate Studies & Selected Studies \\
\hline Science Direct & 65 & 12 & 9 \\
ACM DL & 23 & 15 & 5 \\
Google Schoolar & 25 & 22 & 4 \\
\hline Total & 113 & 49 & 18 \\
\hline
\end{tabular}

Tabel 3. Source of Publication and Paper Concept

\begin{tabular}{|c|c|c|c|c|}
\hline NO & Author (s) & Journal Name & Source & Concept \\
\hline 1 & $\begin{array}{l}\text { Pedro Mendi, Rodrigo } \\
\text { Costamagna }\end{array}$ & $\begin{array}{l}\text { Managing innovation under competitive } \\
\text { pressure from informal producers }\end{array}$ & $\begin{array}{lr}\text { Technological } & \text { Forecasting } \\
\text { and Social } & \text { Change, } \\
\text { Volume } 114 & \\
\end{array}$ & $\begin{array}{l}\text { Management } \\
\text { Innovation }\end{array}$ \\
\hline 2 & $\begin{array}{l}\text { Christoph Grimpe, } \\
\text { Wolfgang Sofka }\end{array}$ & $\begin{array}{l}\text { Complementarities in the search for } \\
\text { innovation-Managing } \\
\text { relationships }\end{array}$ & $\begin{array}{l}\text { Research Policy, Volume } \\
45 \text {, Issue 10, December } \\
2016\end{array}$ & $\begin{array}{l}\text { Management } \\
\text { Innovation }\end{array}$ \\
\hline 3 & $\begin{array}{l}\text { Jonas Van Lancker, } \\
\text { Erwin Wauters, Guido } \\
\text { Van Huylenbroeck }\end{array}$ & $\begin{array}{l}\text { Managing innovation in the bioeconomy: } \\
\text { An open innovation perspective }\end{array}$ & $\begin{array}{l}\text { Biomass and Bioenergy, } \\
\text { Volume } 90 \text {, July } 2016\end{array}$ & $\begin{array}{l}\text { Management } \\
\text { Innovation }\end{array}$ \\
\hline 4 & Ines Mergel & $\begin{array}{l}\text { Agile innovation management } \\
\text { government: A research agenda }\end{array}$ & 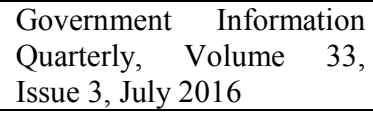 & $\begin{array}{l}\text { Standard } \\
\text { Innovation }\end{array}$ \\
\hline
\end{tabular}




\begin{tabular}{|c|c|c|c|c|}
\hline$\overline{\text { NO }}$ & Author (s) & Journal Name & Source & Concept \\
\hline 5 & $\begin{array}{lr}\text { Marcelo } & \text { Seido Nagano, } \\
\text { Juliano } & \text { Pavanelli } \\
\text { Stefanovitz, } & \text { Thais } \\
\text { Elaine Vick } & \end{array}$ & $\begin{array}{l}\text { Innovation management processes, their } \\
\text { internal organizational elements and } \\
\text { contextual factors: An investigation in } \\
\text { Brazil }\end{array}$ & $\begin{array}{l}\text { Journal of Engineering and } \\
\text { Technology Management, } \\
\text { Volume } 33 \text {, July- } \\
\text { September } 2014\end{array}$ & $\begin{array}{l}\text { Management } \\
\text { Innovation }\end{array}$ \\
\hline 6 & $\begin{array}{l}\text { Paulo Henrique de } \\
\text { Souza Bermejo et al }\end{array}$ & $\begin{array}{l}\text { Conceptualizing organizational innovation: } \\
\text { The case of the Brazilian software industry }\end{array}$ & $\begin{array}{l}\text { Information } \quad \& \\
\text { Management, Volume } 53 \text {, } \\
\text { Issue 4, June 2016 }\end{array}$ & $\begin{array}{l}\text { Standard } \\
\text { Innovation }\end{array}$ \\
\hline 7 & Heiko Gebauer & $\begin{array}{l}\text { Exploring the contribution of management } \\
\text { innovation to the evolution of dynamic } \\
\text { capabilities }\end{array}$ & $\begin{array}{l}\text { Industrial } \quad \text { Marketing } \\
\text { Management, Volume 40, } \\
\text { Issue 8, November 2011 }\end{array}$ & $\begin{array}{l}\text { Management } \\
\text { Innovation }\end{array}$ \\
\hline 8 & $\begin{array}{l}\text { Benoit A. Aubert, Rajiv } \\
\text { Kishore, Akie Iriyama }\end{array}$ & $\begin{array}{l}\text { Exploring and managing the "innovation } \\
\text { through outsourcing" paradox }\end{array}$ & $\begin{array}{l}\text { The Journal of Strategic } \\
\text { Information } \\
\text { Volume 24, Issue 4, } \\
\text { December } 2015\end{array}$ & $\begin{array}{l}\text { Management } \\
\text { Innovation }\end{array}$ \\
\hline 9 & $\begin{array}{l}\text { Giselle Rampersad, } \\
\text { Carolin Plewa, Indrit } \\
\text { Troshani }\end{array}$ & $\begin{array}{l}\text { Investigating the use of information } \\
\text { technology in managing innovation: A case } \\
\text { study from a university technology transfer } \\
\text { office }\end{array}$ & $\begin{array}{l}\text { Journal of Engineering and } \\
\text { Technology Management, } \\
\text { Volume 29, Issue 1, } \\
\text { January-March } 2012\end{array}$ & $\begin{array}{l}\text { Investigation } \\
\text { Innovation }\end{array}$ \\
\hline 10 & $\begin{array}{l}\text { Per Levén, } \\
\text { Jonny Holmström, Lars } \\
\text { Mathiassen }\end{array}$ & $\begin{array}{l}\text { Managing research and innovation } \\
\text { networks: Evidence from a government } \\
\text { sponsored cross-industry program }\end{array}$ & $\begin{array}{l}\text { Research Policy, Volume } \\
\text { 43, Issue 1, February } 2014\end{array}$ & $\begin{array}{l}\text { Investigation } \\
\text { Innovation }\end{array}$ \\
\hline 11 & $\begin{array}{l}\text { Giselle Rampersad, } \\
\text { Pascale Quester, Indrit } \\
\text { Troshani }\end{array}$ & \begin{tabular}{lcr} 
Managing & innovation & \multicolumn{2}{r}{ networks: } \\
Exploratory & evidence & from ICT, \\
biotechnology & and & nanotechnology \\
networks & & \\
\end{tabular} & 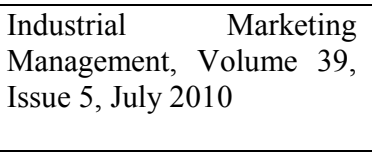 & $\begin{array}{l}\text { Management } \\
\text { Innovation }\end{array}$ \\
\hline 12 & Cheng-Hua Tzeng & $\begin{array}{l}\text { Managing innovation for economic } \\
\text { development in greater China: The origins } \\
\text { of Hsinchu and Zhongguancun }\end{array}$ & $\begin{array}{l}\text { Technology in Society, } \\
\text { Volume 32, Issue 2, May } \\
\text { 2010, Pages 110-121 }\end{array}$ & $\begin{array}{l}\text { Management } \\
\text { Innovation }\end{array}$ \\
\hline 13 & $\begin{array}{lrr}\text { Jaka } & \text { Lindič, } & \text { Peter } \\
\text { Baloh, } & \text { Vincent } & \text { M. } \\
\text { Ribière, } & \text { Kevin } & \text { C. } \\
\text { Desouza } & & \\
\end{array}$ & $\begin{array}{l}\text { Deploying information technologies for } \\
\text { organizational innovation: Lessons from } \\
\text { case studiesl }\end{array}$ & $\begin{array}{l}\text { International Journal of } \\
\text { Information Management, } \\
\text { Volume 31, Issue 2, April } \\
2011, \mathrm{P}\end{array}$ & $\begin{array}{l}\text { Standard } \\
\text { Innovation }\end{array}$ \\
\hline 14 & $\begin{array}{l}\text { Donna J. Kelley, Gina } \\
\text { Colarelli } \quad \text { O'Connor, } \\
\text { Heidi Neck, Lois Peters }\end{array}$ & $\begin{array}{l}\text { Building an organizational capability for } \\
\text { radical innovation: The direct managerial } \\
\text { role }\end{array}$ & $\begin{array}{l}\text { Journal of Engineering and } \\
\text { Technology Management, } \\
\text { Volume 28, Issue 4, } \\
\text { October-December 2011, } \\
\text { Pages 249-267 }\end{array}$ & $\begin{array}{l}\text { Management } \\
\text { Innovation }\end{array}$ \\
\hline 15 & $\begin{array}{l}\text { Jane G. Payumo, Prema } \\
\text { Arasu, Anas } \begin{array}{l}\text { Miftah } \\
\text { Fauzi, }\end{array} \text { Iskandar } \\
\text { Zulkarnaen } \\
\text { Deni Noviana }\end{array}$ & $\begin{array}{l}\text { An entrepreneurial, research-based } \\
\text { university model focused on intellectual } \\
\text { property management for economic } \\
\text { development in emerging economies: The } \\
\text { case of Bogor Agricultural University, } \\
\text { Indonesia }\end{array}$ & $\begin{array}{l}\text { World Patent Information, } \\
\text { Volume 36, March 2014, } \\
\text { Pages 22-31 }\end{array}$ & $\begin{array}{l}\text { Standard } \\
\text { Innovation }\end{array}$ \\
\hline 16 & $\begin{array}{lcr}\text { Sara Jansen } & \text { Perry, } \\
\text { Emily } \quad \text { M. Hunter, } \\
\text { Steven C. } \text { Currall }\end{array}$ & $\begin{array}{l}\text { Managing the innovators: Organizational } \\
\text { and professional commitment among } \\
\text { scientists and engineers }\end{array}$ & $\begin{array}{l}\text { Research Policy, Volume } \\
\text { 45, Issue 6, July 2016, } \\
\text { Pages } 1247-1262\end{array}$ & $\begin{array}{l}\text { Management } \\
\text { Innovation }\end{array}$ \\
\hline 17 & $\begin{array}{l}\text { Mikel Zubizarreta, Jesús } \\
\text { Cuadrado, Jon Iradi, } \\
\text { Harkaitz García, Aimar } \\
\text { Orbe }\end{array}$ & $\begin{array}{l}\text { Innovation evaluation model for macro- } \\
\text { construction sector companies: A study in } \\
\text { Spain }\end{array}$ & $\begin{array}{l}\text { Evaluation and Program } \\
\text { Planning, Volume 61, April } \\
\text { 2017, Pages 22-37 }\end{array}$ & $\begin{array}{l}\text { Model } \\
\text { Innovation }\end{array}$ \\
\hline 18 & $\begin{array}{l}\text { Moises Mir, Martí } \\
\text { Casadesús, Luc Honore } \\
\text { Petnji }\end{array}$ & $\begin{array}{l}\text { The impact of standardized innovation } \\
\text { management systems on innovation } \\
\text { capability and business performance: An } \\
\text { empirical study }\end{array}$ & $\begin{array}{l}\text { Journal of Engineering and } \\
\text { Technology Management, } \\
\text { Volume 41, July-September } \\
2016, \text { Pages 26-44 }\end{array}$ & $\begin{array}{l}\text { Standard } \\
\text { Innovation }\end{array}$ \\
\hline
\end{tabular}

\section{CONCLUSION}

Based on this study, we can conclude that almost of the authors of managing innovation deduced that managing innovation is necessary to increase the ability of company to achieve competitive advantage and enhance company performance.

As seen on Table 3, in general, authors and researchers concluded that in addition to produce performance, managing innovation also aims to establish a standard of innovation. 


\section{REFERENCE}

[1] Benoit A. Aubert, Rajiv Kishore, Akie Iriyama. (2015). Exploring and managing the "innovation through outsourcing” paradox. The Journal of Strategic Information Systems, Volume 24, Issue 4, December 2015

[2] Blaxter, L., Hughes, C., and Tight, M. (2010). "How to research (4th ed.)". Buckingham. Open University Press

[3] Cheng-Hua Tzeng (2010), Managing innovation for economic development in greater China: The origins of Hsinchu and Zhongguancun, Technology in Society, Volume 32, Issue 2, May 2010, Pages 110-121

[4] Christoph Grimpe, Wolfgang Sofka. (2016). Complementarities in the search for innovation-Managing markets and relationships. Research Policy, Volume 45, Issue 10

[5] Donna J. Kelley, Gina Colarelli O’Connor, Heidi Neck, Lois Peters (2011). Building an organizational capability for radical innovation: The direct managerial role, Journal of Engineering and Technology Management, Volume 28, Issue 4, October-December 2011, Pages 249-267

[7] Giselle Rampersad, Carolin Plewa, Indrit Troshani. (2012). Investigating the use of information technology in managing innovation: A case study from a university technology transfer office. Journal of Engineering and Technology Management, Volume 29, Issue 1, January-March 2012

[8] Giselle Rampersad, Pascale Quester, Indrit Troshani (2010). Managing innovation networks: Exploratory evidence from ICT, biotechnology and nanotechnology networks. Industrial Marketing Management, Volume 39, Issue 5, July 2010, Pages 793-805

[9] Heiko Gebauer. (2011). Exploring the contribution of management innovation to the evolution of dynamic capabilities. Industrial Marketing Management, Volume 40, Issue 8, November 2011

[10] Ines Mergel. (2016). Agile innovation management in government: A research agenda. Government Information Quarterly, Volume 33, Issue 3.

[11] Jaka Lindič, Peter Baloh, Vincent M. Ribière, Kevin C. Desouza (2011), Deploying information technologies for organizational innovation: Lessons from case studies,_International Journal of Information Management, Volume 31, Issue 2, April 2011, Pages 183-188

[12] Jane G. Payumo, Prema Arasu, Anas Miftah Fauzi, Iskandar Zulkarnaen Siregar, Deni Noviana, An entrepreneurial, research-based university model focused on intellectual property management for economic development in emerging economies: The case of Bogor Agricultural University, Indonesia, World Patent Information, Volume 36, March 2014, Pages 22-31

[13] Joe Tidd and John Bessant. (2009). Mananging Innovation Integrating Technological, Market and Organizational Change. $4^{\text {th }}$ edition, John Wiley and Son

[14] Jonas Van Lancker, Erwin Wauters, Guido Van Huylenbroeck. (2016). Managing innovation in the bioeconomy: An open innovation perspective. Biomass and Bioenergy, Volume 90

[15] Kimiz Dalkir. (2011). Knowledge Management in theory and Practice $2^{\text {ed }}$.The MIT Press Cambriddge

[16] Kitchenham, B. (2004). Procedures for Performing Systematic Reviews. Keele, UK, Keele University, 33(2004), 1-26.

[17] Kotler, J.P., dan Heskett, J.L. (1992). Corporate Culture and Performance. New York: The Free Press

[18] Marcelo Seido Nagano, Juliano Pavanelli Stefanovitz, Thais Elaine Vick. (2014). Innovation management processes, their internal organizational elements and contextual factors: An investigation in Brazil. Journal of Engineering and Technology Management, Volume 33.

[19] Meyliana, Hidayanto,A.N., Budiardjo.,E.K. (2015). "The critical success factors for customer relationship management implementation: a systematic literature review" T. Int. J Business Information Systems

[20] Mikel Zubizarreta, Jesús Cuadrado, Jon Iradi, Harkaitz García, Aimar Orbe (2017), Innovation evaluation model for macro-construction sector companies: A study in Spain, Evaluation and Program Planning, Volume 61, April 2017, Pages 22-37

[21] Moises Mir, Martí Casadesús, Luc Honore Petnji (2016). The impact of standardized innovation management systems on innovation capability and business performance: An empirical study, Journal of Engineering and Technology Management, Volume 41, July-September 2016, Pages 26-44

[22] Mol. M.J., dan Birkinshaw, J. (2008). Giant Steps in Management: Creating Innovations that Change the Way We Work. Prentice Hall/Financial Times

[23] Nunan, D. (1992). "Research Methods in Language Learning". Cambridge: Cambridge University Press

[24] Paulo Henrique de Souza Bermejo et al. (2016). Conceptualizing organizational innovation: The case of the Brazilian software industry. Information \& Management, Volume 53, Issue 4,

[25] Pearce, I.I., John, A., Robinson, dan Richard, B. (2013). Strategic Management: Formulation, Implementation, and Control. New York: McGraw Hill.

[26] Pedro Mendi, Rodrigo Costamagna (2017). Managing innovation under competitive pressure from 
informal producers, Technological Forecasting and Social Change, Volume 114, January 2017, Pages 192-202

[27] Pedro Mendi, Rodrigo Costamagna. (2014). Managing innovation under competitive pressure from informal producers. Technological Forecasting and Social Change, Volume 114

[28] Per Levén, Jonny Holmström, Lars Mathiassen (2014). Managing research and innovation networks: Evidence from a government sponsored cross-industry program, Research Policy, Volume 43, Issue 1, February 2014, Pages 156-168.

[29] Porter, M And Heppelman. (2014). How Smart Connecting People. Harvard Busibnes Reviews

[30] Ridley, Diana. (2012). "The Literature Review". SAGE

[31] Sara Jansen Perry, Emily M. Hunter, Steven C. Currall (2016). Managing the innovators: Organizational and professional commitment among scientists and engineers. Research Policy, Volume 45, Issue 6, July 2016, Pages 1247-1262

\section{LIST OF REFERENCES AND ABSTRACTS}

1. Managing innovation under competitive pressure from informal producers

Original Research Article

Technological Forecasting and Social Change, Volume 114, January 2017, Pages 192-202

Pedro Mendi, Rodrigo Costamagna

\section{Abstract}

The existence of a large informal sector may be a factor constraining formal firms' choices of innovation strategies in many developing countries. This paper addresses this issue and studies the impact on innovation of competition against firms in the informal sector. Using the World Bank's Enterprise Survey data from a sample of African and Latin American countries, we find that the marginal impact of informality on innovation by formal firms decreases with the intensity of competitive pressure from informal firms, consistent with an inverted-U relationship between propensity to innovate and competitive pressure from firms in the informal sector. This pattern arises even after controlling for the number of competitors, suggesting that the pressure that informal firms exert on formal firms go beyond a mere increase in the number of competitors.

\section{Complementarities in the search for innovation-Managing markets and relationships} Original Research Article

Research Policy, Volume 45, Issue 10, December 2016, Pages 2036-2053

Christoph Grimpe, Wolfgang Sofka

\section{Abstract}

Extant research has characterized a firm's search for external knowledge in its innovation activities as either relational or transactional in nature. The former implies that a firm chooses and develops collaborative relationships with knowledge sources like universities, customers or suppliers, while the latter suggests transactions governed by markets for technology. We argue that prior literature has ignored that both search strategies are interrelated and complementary: adopting one strategy has a higher marginal return on innovation performance if the other one is present. Moreover, we suggest the benefits from complementarity to be higher when a firm is more distant to the technological frontier in the industry and when markets for technology in that industry are shallow. We test our hypotheses on a sample of 3921 German firms from 2001 to 2009 and find support for our hypotheses.

\section{Managing innovation in the bioeconomy: An open innovation perspective} Original Research Article

Biomass and Bioenergy, Volume 90, July 2016, Pages 60-69

Jonas Van Lancker, Erwin Wauters, Guido Van Huylenbroeck

\section{Abstract}

The transition towards a bioeconomy is increasingly viewed by both policy makers and scholars as one of the primary ways to reduce our dependency on fossil resources. However, socio-economic research on the transition towards the bioeconomy at the firm-level remains scarce. Specifically, studies approaching the bioeconomy from the technology and innovation management (TIM) concepts are particularly uncommon, although the importance of knowledge generation and innovation is considered crucial to make the transition towards a greener economy. In this study, we take a first step in addressing this issue by developing a set of guiding principles for the management of innovation processes in the bioeconomy comprised in three key issues: the relevant stakeholder groups and their importance in innovation development within the bioeconomy, the innovation network strategy and management, and organizational features considered prerequisites for collaborative innovation. This called for an identification of influencing factors specific to the bioeconomy context and the establishment of basic characteristics of innovation processes in the bioeconomy. The five identified influencing factors, the basic innovation process characteristics, and the guidelines and recommendations presented in this paper are based on insights derived from a four-staged literature research of the bioeconomy and TIM literature. In particular, we 
focused on the Open Innovation approach because of the evident fit between this approach and the requirements for innovation in the bioeconomy.

4. Agile innovation management in government: A research agenda

Original Research Article

Government Information Quarterly, Volume 33, Issue 3, July 2016, Pages 516-523

Ines Mergel

\section{Abstract}

Governments are facing an information technology upgrade and legacy problem: outdated systems and acquisition processes are resulting in high-risk technology projects that are either over budget or behind schedule. Recent catastrophic technology failures, such as the failed launch of the politically contested online marketplace Healthcare.gov in the U.S. were attributed to an overreliance on external technology contractors and failures to manage large-scale technology contracts in government. As a response, agile software development and modular acquisition approaches, new independent organizational units equipped with fast reacting teams, in combination with a series of policy changes are developed to address the need to innovate digital service delivery in government. This article uses a process tracing approach, as well as initial qualitative interviews with a subset of executives and agency-level digital services members to provide an overview of the existing policies and implementation approaches toward an agile innovation management approach. The article then provides a research framework including research questions that provide guidance for future research on the managerial implementation considerations necessary to scale up the initial efforts and move toward a collaborative and agile innovation management approach in government.

5. Innovation management processes, their internal organizational elements and contextual factors: An investigation in Brazil

Original Research Article

Journal of Engineering and Technology Management, Volume 33, July-September 2014, Pages 63-92

Marcelo Seido Nagano, Juliano Pavanelli Stefanovitz, Thais Elaine Vick

\section{Abstract}

The aim of this study is to analyze the relationships between internal organizational elements and the influence of contextual factors related to innovation management and its challenges. Four companies that have relevant product development activities in Brazil are studied. This topic was chosen due to the lack of empirical studies that analyze the reality of innovation practices in developing countries. Main results indicate the high interdependence between organizational context and consistency of innovation processes and the influence of organizational structures on how initiatives flow through innovation processes. Among the contributions for existing research and practice, two potential patterns of behaviour guided by two of the main challenges concerning innovation in the literature and in the case studies were identified: managing uncertainty and crossfunctional orchestration.

\section{Conceptualizing organizational innovation: The case of the Brazilian software industry} Original Research Article

Information \& Management, Volume 53, Issue 4, June 2016, Pages 493-503

Paulo Henrique de Souza Bermejo, Adriano Olímpio Tonelli, Robert D. Galliers, Tiago Oliveira, André Luiz Zambalde

\section{Abstract}

This paper presents and tests a conceptual model that explains the innovation practices and innovation outcomes in Brazilian software firms. In terms of internal and external innovation capabilities, the ability to manage the relationship between people and their organizational contexts plays an important role in organizational innovation. Based on these results, we propose that the disparities between software firms in building organizational innovation can be attributed, in part, to differences in their internal capabilities. The paper aims at encouraging and supporting managers to develop internal capabilities as a means of effectively leveraging the internally and externally distributed knowledge essential to innovation development.

\section{Exploring the contribution of management innovation to the evolution of dynamic capabilities} Original Research Article

Industrial Marketing Management, Volume 40, Issue 8, November 2011, Pages 1238-1250

Heiko Gebauer

\section{Abstract}

Companies that find innovative ways to manage capabilities gain competitive advantages. The results of multiple case studies of capital goods manufacturing companies suggest that management innovation contributes to dynamic capabilities. The findings confirm the importance of sensing, seizing, and reconfiguring as dynamic capabilities. Management innovation differs in terms of whether it contributes to sensing, seizing, or reconfiguring. The findings describe issues of management innovation, such as key change agents and utilization (motivation, invention, implementation, as well as theorizing and labeling), which facilitate sensing, seizing, and 
reconfiguring. Maintaining capability-driven competitive advantages is not limited to the innovation of products and services, but should also address management innovation that drives dynamic capabilities. The present study relies on a novel conceptualization of dynamic capabilities through management innovation. This conceptualization advances theory-building on the issue of dynamic capabilities.

\section{Exploring and managing the "innovation through outsourcing" paradox} Original Research Article

The Journal of Strategic Information Systems, Volume 24, Issue 4, December 2015, Pages 255-269

Benoit A. Aubert, Rajiv Kishore, Akie Iriyama

\section{Abstract}

This paper identifies the conditions that create a paradox when firms try to obtain innovation using outsourcing contracts. While outsourcing can be a way to obtain new ideas from business partners, most of the guidelines related to good contract management seem to deter innovative behavior. Managers trying to innovate using outsourcing are therefore facing two opposing sets of constraints, and have to manage both at the same time. In this paper, the nature of the "innovation through outsourcing" paradox is discussed in terms of the tensions between a contractual view of outsourcing and an innovation view of outsourcing, along with their associated reinforcing cycles. The paper outlines four mechanisms that are essentially self-correcting cycles. They include: 1) dual formal reviews; 2) matching governance with level of innovation focus; 3) dynamic decisionmaking/"extreme contracting"; and 4) ambidextrous organization. These can enable managers to deal with this paradox and obtain innovation from outsourcing arrangements in a successful manner. Complexities involved in implementing these mechanisms are discussed and some avenues for future research are offered.

9. Investigating the use of information technology in managing innovation: A case study from a university technology transfer office

Original Research Article

Journal of Engineering and Technology Management, Volume 29, Issue 1, January-March 2012, Pages 3-21

Giselle Rampersad, Carolin Plewa, Indrit Troshani

\section{Abstract}

This study investigates the use of information technology to manage innovation. It is based on a case study on the adoption of an innovation application, which provides an interface between R\&D, marketing and administration functions of innovation development. Drawing on qualitative evidence including a focus group and 16 in-depth interviews, this study contributes by integrating technology acceptance constructs to innovation process performance and marketing literature, as well as by investigating technology acceptance in an innovation context. Implications are discussed for organizations engaged with R\&D or innovation process management and suggestions for research directions are offered.

10. Managing research and innovation networks: Evidence from a government sponsored cross-industry program

Original Research Article

Research Policy, Volume 43, Issue 1, February 2014, Pages 156-168

Per Levén, Jonny Holmström, Lars Mathiassen

\section{Abstract}

Important innovations are increasingly produced based on research engagement and fertilization across industries. However, we know little about the challenges associated with managing innovation networks in specific contexts that involves researchers in cross-industry collaboration. Against this backdrop, we draw on theory on design and orchestration of innovation networks to analyze a large-scale government sponsored program, "ProcessIT Innovations" that was designed to increase competitiveness and accelerate economic growth in Northern Sweden. The program was initiated and led by firms from the traditionally strong local process industry and engaged local researchers and firms from the emerging IT industry. Based on our analyses, we offer two contributions. First, we provide a detailed analysis of the challenges related to configuration of the network, orchestration of partnerships between participants, and facilitation of innovation in dedicated development projects. Second, we propose a model of managing research and innovation networks through fertilization across industries and between firms and research institutions.

11. Managing innovation networks: Exploratory evidence from ICT, biotechnology and nanotechnology networks

Original Research Article

Industrial Marketing Management, Volume 39, Issue 5, July 2010, Pages 793-805

Giselle Rampersad, Pascale Quester, Indrit Troshani

\section{Abstract}

This study examines the management of innovation networks which has enjoyed increased recognition in the marketing literature due to its growing prominence and relevance. By testing a causal model relating network factors to outcomes, the study contributes to theory development on managing innovation at the net level of 
analysis. Consequently, it contributes to the respective marketing literatures on new product development, open innovation, industrial marketing and its emerging network management sub-stream. It also offers a methodological contribution as respondents include key players from businesses, government agencies, research organizations and universities rather than from only one focal organization as studies in extant literature have predominantly done. Findings are based on 219 responses from Australian high technology networks, namely, information and communications technology and biotechnology/nanotechnology. The study offers valuable implications for marketing managers involved in new product development and innovation concerning strategies for managing their inter-organizational innovation initiatives effectively.

12. Managing innovation for economic development in greater China: The origins of Hsinchu and Zhongguancun

Original Research Article

Technology in Society, Volume 32, Issue 2, May 2010, Pages 110-121

Cheng-Hua Tzeng

Original Research Article

Technology in Society, Volume 32, Issue 2, May 2010, Pages 110-121

Cheng-Hua Tzeng

\section{Abstract}

This paper reports on the preliminary findings from a three-year research project exploring the growth of information technology (IT) clusters in Hsinchu, Taiwan and Zhongguancun, China. Drawing on the history of the origins of IT clusters in these two cities, we examine the formation of clusters to understand the mechanisms and factors, such as technological change and institutional reform, which influenced the formation of these clusters. We discuss the issues concerning the process of managing innovation, the conditions that trigger and/or maintain innovation, and the source of technology for innovation. We conclude that successful innovation in origins of IT clusters is a result of the interplay between the state, the market, and the NGOs.

\section{Deploving information technologies for organizational innovation: Lessons from case studies}

International Journal of Information Management, Volume 31, Issue 2, April 2011, Pages 183-188

Jaka Lindič, Peter Baloh, Vincent M. Ribière, Kevin C. Desouza

\section{Abstract}

Organizations must innovate if they are to survive in today's fiercely competitive marketplace. In this paper, we explore how leading organizations are using emerging technologies to enable novel forms of ideation that can radically increase the sheer volume of ideas they explore. In addition, we outline how

organizations use technologies to cost effectively manage this increased volume of ideas by optimizing generation, mobilization, advocacy and screening, experimentation, commercialization, and even the diffusion and implementation of ideas. Critical to this is the management of knowledge during the innovation process.

\section{Building an organizational capability for radical innovation: The direct managerial role} Original Research Article

Journal of Engineering and Technology Management, Volume 28, Issue 4, October-December 2011, Pages 249-267

Donna J. Kelley, Gina Colarelli O’Connor, Heidi Neck, Lois Peters

\section{Abstract}

Our research examines practices for managing project leaders as a component of an organization's capability for radical innovation. Our qualitative analysis of 246 interviews in twelve industry-leading corporations suggests that managers use performance-based assessment to select project leaders with demonstrated experience and skills for innovation, as well as passion that extends beyond a single project toward an awareness of its broader contribution to the organization's growth objectives. The managerial role includes concurrent hands-off/hands-on involvement, which balances autonomy and accountability with guidance. Additionally, downside/upside management involves removing the negative consequences associated with failure while providing recognition for the project leader's efforts.

15. An entrepreneurial, research-based university model focused on intellectual property management for economic development in emerging economies: The case of Bogor Agricultural University, Indonesia Original Research Article

World Patent Information, Volume 36, March 2014, Pages 22-31

Jane G. Payumo, Prema Arasu, Anas Miftah Fauzi, Iskandar Zulkarnaen Siregar, Deni Noviana

\section{Abstract}

Higher education institutions in emerging regions of the world are increasingly expected (largely by their governments and community) to promote regional economic development and national competitiveness. This case study on one of the prominent academic universities in Indonesia - Bogor Agricultural University (Institut Pertanian Bogor, IPB) - highlights its successes and lessons learned in managing intellectual property as an entrepreneurial research-based university. This analysis of IPB provides general and specific insights for 
university administrators, researchers, and policy makers, especially in emerging economies, on appropriate strategies and measures in promoting synergies between research, entrepreneurialism and technology commercialization. The model provides strategies to maximize university research outputs, knowledge transfer and innovation to empower regional communities, and promote strategic and transformational partnerships, private sector engagement and economic growth opportunities for both the institution and the region.

16. Managing the innovators: Organizational and professional commitment among scientists and engineers

Original Research Article

Research Policy, Volume 45, Issue 6, July 2016, Pages 1247-1262

Sara Jansen Perry, Emily M. Hunter, Steven C. Currall

\section{Abstract}

How can leaders best manage commitment among innovators? We applied theory on dual allegiance to multiple targets of commitment, in conjunction with person-organization fit theory, to explore the dynamics of organizational and professional commitment among scientists and engineers working in hybrid, research-focused organizations. These types of organizations are founded on large-scale multi-disciplinary and multi-institutional collaboration between academe and industry. Using both individual- and organizational-level variables collected from 255 academic science and engineering researchers working in 22 National Science Foundation-funded Engineering Research Centers, our analyses revealed that researcher innovation orientation (i.e., the predisposition to approach work in novel ways) was positively associated with organizational and professional commitment. Those relationships were moderated by two factors: organizational productivity in late-stage technology transfer and the researcher's perceived role significance (i.e., in fulfilling the strategic mission of the organization). The strongest positive relationship between innovation orientation and organizational commitment emerged among researchers who perceived high role significance and worked in highly productive organizations. A negative relationship between innovation orientation and professional commitment also emerged among those individuals. Post-hoc analyses revealed that highly innovative, senior researchers who perceived high role significance were the most likely to report higher levels of both organizational and professional commitment. Leaders of multi-disciplinary research centers who are aware of the complexity of dynamics among organizational commitment, professional commitment, and role significance may be better equipped to effectively manage science and engineering researchers.

\section{Innovation evaluation model for macro-construction sector companies: A study in Spain} Original Research Article

Evaluation and Program Planning, Volume 61, April 2017, Pages 22-37

Mikel Zubizarreta, Jesús Cuadrado, Jon Iradi, Harkaitz García, Aimar Orbe

\section{Abstract}

The innovativeness of the traditional construction sector, composed of construction companies or contractors, is not one of its strong points. Likewise, its poor productivity in comparison with other sectors, such as manufacturing, has historically been criticized. Similar features are found in the Spanish traditional construction sector, which it has been described as not very innovative. However, certain characteristics of the sector may explain this behavior; the companies invest in $\mathrm{R}+\mathrm{D}$ less than in other sectors and release fewer patents, so traditional innovation evaluation indicators do not reflect the true extent of its innovative activity. While previous research has focused on general innovation evaluation models, limited research has been done regarding innovation evaluation in the macro-construction sector, which includes, apart from the traditional construction companies or contractors, all companies related to the infrastructure life-cycle. Therefore, in this research an innovation evaluation model has been developed for macro-construction sector companies and is applied in the Spanish case. The model may be applied to the macro-construction sector companies in other countries, requiring the adaption of the model to the specific characteristics of the sector in that country, in consultation with a panel of experts at a national level.

18. The impact of standardized innovation management systems on innovation capability and business performance: An empirical study

Original Research Article

Journal of Engineering and Technology Management, Volume 41, July-September 2016, Pages 26-44

Moises Mir, Martí Casadesús, Luc Honore Petnji

Abstract

This paper provides a novel analysis concerning the impact of a Standardized Innovation Management System (SIMS) on company innovation capability, innovation performance, and corporate results that is an unprecedented contribution to innovation management literature. This research is focused on the standard UNE 166002 that is one of the first national certifiable SIMSs that exists globally. It is one of the first SIMSs in the world that has reached a sufficient level of acceptance to enable an empirical study. In order to analyze its impact on companies, a relational model was developed and analyzed using hypotheses concerning with the 
main dimensions.

Bionote

${ }^{1}$ Eddy Irsan Siregar lecture at the Faculty of Economics \& Business, University Muhammadiyah Of Jakarta, Indonesia. He holds an Doctor Business Management, He also consult in area of Managing Innovation and Strategies for the largest Indonesia SOE's Construction Service. In addition, he acts as member of Association of Teachers and Research in Asia (http:/atera.org). 